NATALIJA DIMIĆ, MA istoričar

Zemun, Bežanijska 55

UDK 94:327(497.1:430.2)"1957"(093.2)

341.7(497.1:430.2)"1950/1957"(093.2)

\title{
SLIKA JUGOSLAVIJE U ISTOČNONEMAČKOJ ŠTAMPI 1957. GODINE
}

\begin{abstract}
APSTRAKT: Analizom pisanja tri istočnonemačka dnevna lista o Jugoslaviji u godini diplomatskog priznanja Nemačke Demokratske Republike od strane Jugoslavije sagledana je slika koja je čitaocima nuđena o jugoslovenskoj državi, njenoj spoljnoj politici, društvenim prilikama, ekonomskim odnosima. Osnovni izvor prilikom pisanja rada predstavljala su tri dnevna lista Istočne Nemačke (Neues Deutschland, Berliner Zeitung, Neue Zeit). U daljem tekstu se pod istočnonemačka štampa podrazumevaju navedena tri lista.
\end{abstract}

Ključne reči: Jugoslavija, Nemačka Demokratska Republika, Savezna Republika Nemačka, SSSR, štampa, propaganda

Svet „provučen“ kroz štamparsku presu ne može biti pravi i potpun odraz stvarnosti, već njegova dvodimenzionalna predstava. Stoga ni istoričar u susretu sa štampom kao izvorom o prošlosti ne treba od nje da očekuje nepristrasnu naraciju, niti potpunu hroniku događaja. Slobodna štampa bila je ideal kojem se težilo od 18. veka, ideal epohe prosvetiteljstva, utkan u liberalno shvatanje medija, koji, po njemu, treba da budu u službi javnosti, oblikovani potražnjom, profesionalnim interesima medijskih radnika i društvenim vrednostima. Iako je štampa u stvarnosti kontrolisana od strane vlasnika, određenih društvenih klasa ili grupa, ekonomskih i drugih interesa, politike, ideal nezavisne štampe da slobodno pretresa sva javna pitanja bez gnjeva i bez pristrasnosti ${ }^{1}$ opstajao je. ${ }^{2}$ Tri lista koja su izlazila u Istočnoj Nemačkoj, a koja su bila predmet analize prilikom izrade ovog rada, nisu,

${ }^{1}$ Zadatak nezavisne štampe, Politika, 12. januar 1904, 1 (http://serbia-forum. mi. sanu. ac. $\mathrm{rs} / \mathrm{wb} /$ ?action=getbook\&bookkey=859\#page $/ 0 /$ mode $/ 1$ up 20 . septembar 2014).

${ }^{2}$ Dž. Karan, Novine. Sociologija štampe, u: „Uvod u studije medija“, (prir. A. Brigs, P. Kobli), Beograd 2005, 135-156; A. Brigs, P. Berk, Društvena istorija medija, Beograd 2006, 268-285; Dž. Tjurou, Mediji danas. Uvod u masovne komunikacije, knj. I, Beograd 2012, 419-420. 
međutim, ni nastojala da budu predstavnici nezavisne štampe. ${ }^{3} \mathrm{Na}$ naslovnim stranicama njihovih prvih brojeva najavljena je obnova, izgradnja novog društva, borba protiv nacizma, prijateljstvo sa sovjetskim narodom, ${ }^{4}$ novo vreme, ${ }^{5}$ najavljena je budućnost i borba za mir na osnovama demokratije i jedinstva, uz Jedinstvenu socijalističku partiju Nemačke. ${ }^{6}$ Liberalno shvatanje da štampa treba da omogući pun i slobodan pristup informacijama, znanju, da treba da podstiče diskusiju i dvosmernu komunikaciju, ${ }^{7} \mathrm{u}$ dnevnim listovima Istočne Nemačke zamenjeno je praksom jednosmerne komunikacije ograničenog korpusa informacija od vladajućeg vrha ka čitaocima. "Nojes Dojčland“ (Neues Deutschland, Nova Nemačka) bio je svenemački list i zvanični organ Jedinstvene socijalističke partije Nemačke, ogledalo oficijalnih partijskih stavova, ali i izveštač o aktuelnim umetničkim, književnim, sportskim, društvenim dešavanjima. ${ }^{8}$ Drugi list koji smo koristili, takođe izdavan od strane Jedinstvene socijalističke partije Nemačke, bio je lokalni, ali uticajni, istočnoberlinski dnevni list „Berliner Cajtung“ (Berliner Zeitung, Berlinske novine), osnovan u maju 1945. godine, koji i danas izlazi. ${ }^{9}$ Treći list „Noje Cajt“ (Neue Zeit, Novo vreme) bio je organ Hrišćansko-demokratske unije u Istočnoj Nemačkoj. Spektrom tema o crkvi i religiji obraćao se krugu čitalaca do kojih nisu dopirala glasila Jedinstvene partije. ${ }^{10}$

Za godinu 1957. odlučili smo se iz više razloga. Jedan je bio kvantitativni indikator. Jugoslavija (Jugoslawien) je u godinama 1950-1954. pominjana u proseku oko 230 puta godišnje u sva tri lista zajedno. Interesovanje

${ }^{3} \mathrm{U}$ okviru projekta Presse in der $D D R^{3}$ (Štampa u NDR) digitalizovana su tri pomenuta dnevna lista, kao reprezentativna za uvid u štampu Nemačke Demokratske Republike (NDR). Dostupna su preko sajta Državne biblioteke u Berlinu (Staatsbibliothek zu Berlin http://zefys. staatsbibliothek-berlin.de/), a tim putem smo ih i mi koristili tokom pisanja rada. Projekat je sproveden od strane Nemačkog istraživačkog društva (Deutsche Forschungsgemeinschaft - DFG, http://www.dfg. de/index. jsp) u saradnji sa izdavačkim preduzećima „Neues Deutschland“, „Berliner Verlag“ i „Frankfurter Allgemeine Zeitung“ (sa „Neue Zeit") i projektnim partnerom Centrom za istraživanja savremene istorije iz Potsdama (Zentrum für Zeithistorische Forschung Potsdam - ZZF, http://www.zzf-pdm.de), sa ciljem da se istraživačima stavi na raspolaganje značajan deo dnevne štampe Sovjetske okupacione zone (1945-49) i Nemačke Demokratske Republike (1949-90).

${ }^{4}$ Berlin lebt auf, Berliner Zeitung, 21. maj 1945, 1.

${ }^{5}$ Unsere Zeitung. NEUE ZEIT, Neue Zeit, 22. jul 1945, s. 1.

${ }^{6}$ Manifest an das deutsche Volk, Neues Deutschland, 23. april 1946, s. 1.

${ }^{7}$ A. Brigs, P. Berk, n.d., 275.

${ }^{8}$ Izlazio je u periodu od aprila 1946. do oktobra 1990. Urednik je tokom 1957. bio Herman Aksen (Hermann Axen), 1956-66.

${ }^{9}$ Tokom 1957. smenila su se dva urednika, Erih Henše (Erich Hensche, 1955-57) i Teo Grandi (Theo Grandy, 1957-61).

${ }^{10}$ Izlazio od jula 1945. do jula 1994, urednik je 1957. bio Alvin Šaper (Alwin Schaper 1950-61). 
štampe za Jugoslaviju raslo je uporedo sa sovjetsko-jugoslovenskim približavanjem, te je Jugoslavija 1957. godine pomenuta 964 puta. Posle 1958. godine ređe se pisalo o Jugoslaviji, a zainteresovanost štampe ponovo se pojavila tokom 60-ih godina. Godina 1957. značajna je za nemačkojugoslovenske odnose jer je u oktobru Jugoslavija uspostavila diplomatske odnose sa Istočnom Nemačkom, što je za posledicu imalo prekid odnosa sa Saveznom Republikom Nemačkom (SRN). Pored toga, za razliku od početnog jugoslovensko-istočnonemačkog približavanja, koje je teklo uporedo sa otopljavanjem u odnosima SSSR-FNRJ, promene jugoslovenskog stava prema nemačkom pitanju tokom 1955-56, burne 1956. godine, činilo nam se da tek 1957. godina i uspostavljanje diplomatskih odnosa između Nemačke Demokratske Republike (NDR) i FNRJ donosi značajne događaje koje koliko-toliko ima smisla posmatrati na nivou jugoslovensko-nemačkih relacija. I to bez vizure Sovjetskog Saveza, koji se kao faktor ne sme gubiti iz vida, ali nam usled trenutne nedostupnosti ruskih arhiva i biblioteka nije $\mathrm{u}$ potpunosti saglediv. Dodatni razlog je bila činjenica da su od 1948. do sredine 1950-ih bili prekinuti kontakti na relaciji NDR-FNRJ, pa su mediji bili jedan od retkih kanala putem kojeg su stizale vesti i kroz koji je oblikovana predstava Jugoslavije u Istočnoj Nemačkoj.

Jugoslavija je $\mathrm{u}$ istočnonemačkoj javnosti dominantno bila prisutna u političkom svetlu, ali je postojala i kroz ekonomiju, ideologiju, kao geografski pojam, kroz sport, film, književnost, modu i druge oblasti života. Stekli smo utisak da je čitalac istočnonemačke štampe bio slabo upoznat sa prilikama u Jugoslaviji. Verovatno ni interesovanje za tu nepoznatu zemlju nije bilo veliko.

Šta znamo o Jugoslaviji? Jugoslavija: toliko problema, toliko upitnika. Šta znamo o ovoj zemlji, o putu njenog naroda? U osnovi veoma malo. Od prošle godine, kada su Bulganjin i Hruščov bili u Beogradu, to pogotovo jasno uviđamo. Često se u svetu postavlja pitanje: „Da li je Jugoslavija između Zapada i Istoka?" Oni koji to pitaju ni ne računaju na to da ova zemlja već dve stotine godina leži između Istoka i Zapada, ${ }^{11}$ uvodne su reči teksta posvećenog Jugoslaviji početkom juna 1956. godine.

Podsticaj za bliže upoznavanje sa Jugoslavijom došao je usled jugoslovensko-sovjetskog političkog približavanja. Kakva je slika o Jugoslaviji postojala u nemačkom narodu nakon nacističkog perioda koji je na Jugoistok gledao kao na „dopunski privredni prostor," "agrarni okean," posle ratnih razaranja, nakon gotovo deceniju duge antijugoslovenske politike i osuda "jugoslovenskog puta“? Da li je takva slika bila odgovarajuća za jednu (ponovo afirmisanu) socijalističku državu? Da li je ipak državu koja

${ }^{11}$ Was wissen wir über Jugoslawien. Eine Reise durch das Land zwischen den Alpen und der Adria, Berliner Zeitung, 1. jun 1956, s. 2. 
Nemačkoj Demokratskoj Republici donosi jedan od najznačajnijih spoljnopolitičkih poena $\mathrm{u}$ vidu diplomatskog priznanja trebalo prikazati $\mathrm{u}$ reprezentativnijem svetlu?

Vreme kad se govorilo: „Jugoslavija - nije li to mala agrarna zemlja negde na Balkanu?", pripada prošlosti. ${ }^{12}$. Devetnaestovekovna slika koja se ogleda u izjavi kancelara Bizmarka da "ceo Balkan ne vredi kostiju jednog časnog pomeranskog vojnika“ ... zahteva temeljnu reviziju. ${ }^{13}$

Kroz štampu je trebalo srušiti postojeću, duboko urezanu predstavu Balkana, ali i ponuditi novu sliku, usklađenu sa ideologijom i novouspostavljenim političkim odnosima. Jugoslavija je učinila veliki korak ka industrijskoj zemlji. U njoj se proizvodi sve od igle do broda, jugoslovenski radnici sami sklapaju automobile, turbine, teretna vozila, televizore, sirovine sa jugoslovenskog tla prerađuju se u samoj zemlji. Jugoslavija nije ekonomski i politički zavisna kao predratna država. Tamo gde su nekada bila krda ovaca, sada su visoke peći, pored volovskih zaprega prolaze pruge, kroz nekadašnje močvare moderni drumovi, iznad gradskih krovova ukrašenih antenama preleću „lovci“. Za 12 godina socijalističkog razvojnog puta Jugoslavija je uspela da podigne industriju koja je promenila izgled zemlje. ${ }^{14}$ Tako je predstavljan i slavljen trijumf čoveka nad prirodom, dokazivana nadmoć socijalističkog društvenog i privrednog sistema, dokazivano da je Jugoslavija socijalistička zemlja. Takva je bila željena slika Jugoslavije 16. oktobra, dan po uspostavljanju diplomatskih odnosa. Jugoslavija puna optimizma ali ne samo zbog materijalnih prilika, novih zgrada, punih izloga, čistih i elegantnih ulica, već pre svega zbog ponovo čvrstih odnosa sa Sovjetskim Savezom i narodnim demokratijama, zbog pripadanja krugu socijalističkih zemalja. ${ }^{15}$

Pored slike koje su istočnonemačke vlasti želele da ponude o Jugoslaviji, naslućuje se kroz korišćenu štampu i način na koji je Jugoslavija želela da predstavi sebe. To je vidno kroz opise jugoslovenskih štandova sa sajmova $\mathrm{u}$ Lajpcigu ${ }^{16}$ i Zagrebu, ${ }^{17}$ kroz koje se Jugoslavija predstavljala kao industrijska zemlja, kroz učešće socijalističkih, ali i kapitalističkih zemalja na Zagrebačkom velesajmu, što je od njega činilo posredničko mesto između

12 Jugoslawiens großer Schritt zum Industrieland. Eigene Rohstoffe für eigenen Aufbau / Blick in die Wirtschaft, Berliner Zeitung, 16. oktobar 1957, s. 5.

${ }^{13}$ Die Kirche des heiligen Sava, Neue Zeit, 18. oktobar 1957, s. 2.

14 Jugoslawiens großer Schritt zum Industrieland. Eigene Rohstoffe für eigenen Aufbau / Blick in die Wirtschaft, Berliner Zeitung, 16. oktobar 1957, s. 5.

${ }^{15}$ Jugoslawien voller Optimismus, Berliner Zeitung, 29. novembar 1957, s. 9.

16 Von Maschinen bis Rauchwaren. Jugoslawische Messedelegation in Leipzig, Neue Zeit, 24. februar 1957, s. 5.

${ }^{17}$ Treffpunkt der Kontinente am Save-Ufer. DDR zum drittenmal in Zagreb - Neues Gesicht des Messegeländes, Neue Zeit, 19. septembar 1957, s. 5. 
dva svetska trgovinska sistema, kao i ilustraciju realnih osnova miroljubive koegzistencije zemalja različitog društvenog, državnog i privrednog sistema. ${ }^{18}$ Slika koju je Jugoslavija slala o sebi kao uspešnoj, modernoj, industrijskoj, socijalističkoj zemlji bila je u skladu sa ideologijom, odgovarala je odbrani uspešnosti „jugoslovenskog puta“ u socijalizam, kao i perspektivi ekonomske saradnje sa Nemačkom Demokratskom Republikom.

Delegacijama koje su dolazile u FNRJ pokazivani su muzeji, kulturna baština, ali i gradovi i industrijski centri. Trebalo je prikazati napredak Jugoslavije na svim poljima. ${ }^{19}$ Zvanična delegacija tekstilaca iz NDR posetila je Jugoslaviju u aprilu 1957. i obišla tekstilna, kožna i odevna preduzeća u Beogradu, Zagrebu, Novom Sadu i Borovu. Pored toga, organizovana je i poseta Kragujevcu i humkama žrtava streljanih 1941. godine. ${ }^{20}$ Kao što je propaganda protiv Zapadne Nemačke bila i u svrsi poricanja sopstvene nacističke prošlosti i prebacivanja celokupnog imperijalističkog i nacističkog nasleđa na teret SRN, tako su i odnosi sa Jugoslavijom, kao žrtvom fašističkog napada, imali sličnu funkciju. U jednom tekstu o grupi filmskih stvaralaca koja je tokom leta 1957. boravila u Jugoslaviji sa ciljem snimanja naučnopopularnih emisija, ispričana je epizoda o njihovom privatnom smeštaju u Zagrebu, u porodici čija je ćerka sa 13 godina odvedena u koncentracioni logor u Nemačkoj, a čije su gostoprimstvo, uprkos tome što su Nemci, uživali. Reči koje je domaćin navodno izgovorio, a koje su se autoru teksta urezale u sećanje, bile su: Želim da zaboravimo i da ne otvaramo više tu temu. Mi dobro znamo iz koje Nemačke vi dolazite. ${ }^{21}$ Da li su te reči zaista izgovorene ne znamo, ali je njihovo objavljivanje u štampi svakako imalo i ulogu ograđivanja od sopstvene prošlosti, određenu vrstu iskupljenja kroz socijalizam, koji ne samo što "spira“ nemačku prošlost već i kod bratskog naroda u socijalističkoj Jugoslaviji na prvo mesto stavlja bratstvo i solidarnost, prebacujući celokupnu odgovornost na grupu militarista, fašista, koji su i klasno odvojeni od naroda.

I u kulturnoj politici istočnonemačke države denacifikacija je imala istaknuto mesto. Tematika uvoženih jugoslovenskih filmova najčešće je bila vezana za Drugi svetski rat i antifašističku borbu. U filmskim reportažama podvlačeno je da važnije teme nema, da su filmovi koji se bave fašizmom korisni jer podsećaju na užase koje je ta ideologija proizvela, da se prošlost

18 Erfolge der DDR in ZagrebGute Voraussetzungen für unseren Handel mit Jugoslawien 1958, Neues Deutschland, 3. oktobar 1957, s. 5.

${ }^{19}$ Zusammenarbeit orthodoxer Bruderkirchen. Nach der Jugoslawienreise des Patriarchen Alexej, Neue Zeit, 29. novembar 1957, s. 3.

20 Jugoslawien über Bonner Rüstung besorgt. DDR-Gewerkschafter über ihre Eindrücke aus Gesprächen mit jugoslawischen Arbeitern, Neues Deutschland, 30. april 1957, s. 5.

${ }^{21}$ Mit Camera durch Jugoslawien, Neue Zeit, 29. novembar 1957, s. 3. 
ne sme zaboraviti tim pre što su se pojavili znaci oživljavanja fašizma $u$ Zapadnoj Nemačkoj. ${ }^{22}$ Jugoslovenski filmovi, osim toga, karakterisani su kao uzbudljivi akcioni filmovi u kojima se primećuje uticaj „američke škole“ i „američka tehnička pomoć.“" ${ }^{23}$ Ona je jugoslovenskom filmu davala tempo i atmosferu koja je podsećala na veoma popularne vesterne, činila ga različitim od ostalih istočnoevropskih kinematografija, a ipak je poruka koja je filmovima prenošena bila „ispravna“ antifašistička i socijalistička. Istočnonemačka publika nije bila „zasićena“ filmovima snimljenim u tom maniru. ${ }^{24}$

Šta se još moglo saznati o jugoslovenskoj kinematografiji 1957. iz čitanja istočnonemačke štampe? Pominjana grupa filmskih stvaralaca koja je tokom leta boravila $\mathrm{u}$ Jugoslaviji primetila je da je filmski studio $u$ Zagrebu bio dobro opremljen, iznenađeni su bili činjenicom da mlada jugoslovenska kinematografija ima već 10 produkcija koje se bave kulturnim, dokumentarnim i igranim filmovima. Broj bioskopa je $u$ odnosu na predratni period učetvorostručen, a postojali su i „putujući bioskopi“ koji su prenosili filmsku umetnost (i željene poruke) i stanovnicima sela. ${ }^{25}$ Utisak o usponu kinematografije koji su nemački posetioci poneli iz Jugoslavije verovatno je odraz svesti jugoslovenskog rukovodstva o filmu kao medijumu za prenošenje ispravnih poruka i širenje kulture, koji je popularan i koji neposredno i sugestivno dopire do širokih masa. ${ }^{26}$

Iako filmske reportaže nisu nužno prenosile političku ili propagandnu poruku, preduslov kulturnoj saradnji, pa time i pisanju o „isečcima“ kulture uvezene iz Jugoslavije, bila je politička saradnja. Reportaže, putopisi, dnevničke beleške o poseti Jugoslaviji, pisane tokom prvih meseci i leta 1957. godine, prostor u štampi dobijale su tek na jesen. Na kulturnoj mapi sveta Jugoslavija je $u$ istočnonemačkoj štampi 1957. bila prisutna gotovo jedino kroz film. Uspostavljanje kulturne saradnje između NDR i FNRJ bio je deo ukupne normalizacije partijskih i državnih odnosa i stoga je 1957. bilo tek u začetku. Nije postojala kulturna razmena bez političke saradnje. Da li je Jugoslavija postojala u istočnonemačkoj štampi izvan političkog i neuslovljena političkim?

${ }^{22}$ Fahndung. Ein spannender jugoslawischer Film, Berliner Zeitung, 15. april 1957, s. 3. Blick zurück im Zorn. Eine nord-südliche Film-Koproduktion, Berliner Zeitung, 11. septembar 1957, s. 3.

${ }^{23}$ Berliner Zeitung, 9. jul 1957; Verbrechen am Schienenstrang. Bahnraub in Belgrad“ - efn Kriminalfilm aus Jugoslawien, Neue Zeit, 6. avgust 1957, s. 4.

${ }^{24}$ R. Vučetić, Koka-kola socijalizam. Amerikanizacija jugoslovenske popularne kulture šezdesetih godina XX veka, Beograd 2012, 84-95, 103-110, 125-144.

${ }^{25}$ Mit Camera durch Jugoslawien, Neue Zeit, 29. novembar 1957, s. 3.

${ }^{26}$ R. Vučetić, $n$.d., 83-84. 
Sportske vesti registrovale su učešće Jugoslavije na različitim svetskim takmičenjima. One nisu bile vezane za konkretne jugoslovenskoistočnonemačke odnose, ali je u pitanju bilo samo prenošenje vesti o odigranim utakmicama, rezultatima, trkama, rekordima, te je Jugoslavija kao zemlja sporta bila u vidokrugu samo onih čitalaca štampe koji su pratili sportske vesti. U Jugoslaviji se igrao fudbal, rukomet, vaterpolo, hokej na ledu, tenis, boks, šah, učestvovalo se na auto moto-trkama, upražnjavani su atletika, gimnastika, biciklizam i drugi sportovi. Izvan političkog konteksta Jugoslavija je pominjana povremeno $\mathrm{u}$ vremenskim prognozama. Postojala je kao geografski pojam u ukrštenim rečima u kojima se tražilo poznavanje oblasti, gradova i saveznih republika. U ukrštenicama je više puta postavljano pitanje koja je jugoslovenska valuta, a nekoliko vesti je mapiralo Jugoslaviju i u kontekstu mode.

Tri dnevna lista korišćena prilikom pisanja ovog rada, u kojima su političke vesti bile gotovo identičnog sadržaja, pokazuju više specifičnih interesovanja kada su u pitanju teme iz vanpolitičke sfere. To je najočitije $u$ pisanju lista Noje Cajt, koji posebnu pažnju poklanja temama vezanim za religiju i crkvu. Imajući u vidu da je u pitanju zvanični list Hrišćanskodemokratske unije u Istočnoj Nemačkoj, takva interesovanja ne čude, ali se takođe vidi da su tekstovi, mada o religiji, u skladu sa komunističkom ideologijom i državnom politikom. Isticano je da je odnos crkve i države u socijalističkoj Jugoslaviji dobar, da je crkva je u čvrstoj vezi sa narodom, živa i puna optimizma. Tokom 1957. usled spoljnih manifestacija (poseta stranih crkvenih delegacija, pojavljivanja patrijarha i episkopa na prijemima, državnih subvencija, poseta SIV-u, odluke o poseti Predsedniku...) delovalo je kao da su odnosi između crkve i jugoslovenske države harmonični, te je i dopisnik Noje Cajta verovatno stekao sličan utisak. ${ }^{27}$ Međutim, osim pružanja slike o stanju crkve u Jugoslaviji, cilj istočnonemačke štampe je verovatno bio i da se verujućim čitaocima štampe u NDR ponudi vizija harmoničnih odnosa crkve i socijalističke države, a time i pobudi vera u mogućnost skladnog odnosa crkve i istočnonemačke države.

Stiče se opšti utisak da se o jugoslovenskom prostoru, društvu, istoriji, kulturi, privredi i državi sredinom 50 -ih godina u NDR malo znalo. Već pominjana delegacija industrijalaca koja je Jugoslaviju posetila $u$ aprilu izveštavala je o izgradnji zemlje, ali i o posledicama fašističke okupacije, među kojima su posetili humke žrtava streljanih 21. oktobra 1941. u gradu

${ }^{27}$ Sredina 50-ih godina donela je poboljšanje u odnosima SPC i države, iako se to daleko više osećalo na vrhu nego na nižim nivoima, gde je situacija i dalje bila teška. Patrijarh Vikentije je često javno govorio o poboljšanju odnosa, što je odavalo pozitivan utisak o crkveno-državnoj saradnji. R. Radić, Država i verske zajednice 1945-1970, Drugi deo: 19541970, Beograd 2002, 9-17. 
Kragujevcu u Hrvatskoj. ${ }^{28}$ Iako je u pitanju očigledna greška koja se mogla potkrasti, ona ukazuje na to da čak i oni koji su zapravo bili u Jugoslaviji nisu imali jasnu predstavu o toj zemlji.

Krunu političkih odnosa NDR-FNRJ tokom 1957. godine predstavljalo je uspostavljanje diplomatskih odnosa 15. oktobra. Zainteresovanost istočnonemačke štampe za Jugoslaviju pratila je amplitudu jugoslovenskosovjetskih odnosa, koja se preslikavala i na odnose Jugoslavije sa ostalim socijalističkim zemljama, pa i sa NDR. Stoga je i najveću pažnju istočnonemačka štampa Jugoslaviji posvećivala u jesenjim mesecima. Čak su i tekstovi iz vanpolitičke sfere, koji su slavili socijalističku stvarnost i napredak u Jugoslaviji, bili u direktnoj vezi sa političkim jugoslovensko-istočnonemačkim približavanjem. Ipak, daleko najbrojniji bili su tekstovi političke sadržine. Kakav je bio karakter tih tekstova?

Političke vesti koje su tri dnevna lista korišćena prilikom pisanja ovog rada prenosila bile su gotovo identičnog sadržaja, a neretko su obilovale $\mathrm{i}$ istim rečeničnim sklopovima. To je bila posledica činjenice da je odgovornost za sveukupno političko izveštavanje u NDR bila je u rukama jedne novinske agencije - ADN (Allgemeine Deutsche Nachrtichtdienst), koja je bila pod kontrolom državnog i partijskog vrha. Najčešće su političke vesti preuzimane iz Moskve, ali je bilo i prenošenja vesti iz Praga, Varšave, Budimpešte, Tirane i drugih prestonica. Vesti vezane za OUN stizale su direktno iz Njujorka, ali je uopšteno gledano iz zapadnog sveta retko izveštavano, među vestima posvećenim Jugoslaviji, samo nekoliko efemernih informativnih izveštaja. ${ }^{29}$

Pitanja koja su dobijala prostor $u$ istočnonemačkoj štampi ticala su se konkretnih odnosa FNRJ sa NDR, Sovjetskim Savezom i drugim socijalističkim zemljama. Zainteresovanost štampe postojala je za odnos Jugoslavije prema nemačkom pitanju, kao i za sve jugoslovenske poteze koji bi se mogli iskoristiti protiv Bona.

U velikom broju tekstova istočnonemačke štampe iz 1957. godine posvećenim jugoslovenskoj politici prema nemačkom pitanju, polaznu tačku za objašnjenje jugoslovenskog stava predstavljala je poseta Josipa Broza Tita Moskvi juna 1956, njegov govor održan na stadionu Dinama i zajednička sovjetsko-jugoslovenska deklaracija u kojoj je iskazano postojanje dve

28 Jugoslawien über Bonner Rüstung besorgt. DDR-Gewerkschafter über ihre Eindrücke aus Gesprächen mit. avgust 2014)jugoslawischen Arbeitern, Neues Deutschland, 30. april 1957, s. 5.

${ }^{29}$ H. Puerer, J. Raabe, Presse in Deutschland, 177-192. 
suverene nemačke države. ${ }^{30}$ Iako je jugoslovenska diplomatija takav stav zauzimala i 1955. godine, on se tek 1956. u potpunosti poklapao sa zvaničnim stavom Moskve. Uz to, 1956. godine stav prema nemačkom pitanju iznesen je javno, a N. S. Hruščov se u razgovorima sa jugoslovenskom delegacijom obavezao da će „drugovima u Istočnoj Nemačkoj“ objasniti prirodu jugoslovensko-zapadnonemačkih odnosa. Hruščov je verovatno imao ulogu tumača celokupnog jugoslovenskog stava prema nemačkom pitanju, te se trenutak Moskovske deklaracije urezao u svesti istočnonemačkih rukovodilaca, a tim putem i javnosti, kao prekretnica u jugoslovenskom stavu o Nemačkoj. ${ }^{31}$

Postojao je prvih meseci 1957. godine i načelno pozitivan odnos prema većini jugoslovenskih spoljnopolitičkih principa (zalaganje za mir, ${ }^{32}$ za proleterski internacionalizam i razvoj socijalističkih snaga, ${ }^{33}$ aktivnu miroljubivu koegzistenciju, isticanje da je postojanje dve nemačke države politička realnost i da aktivni učesnik u rešavanju nemačkog pitanja mora biti nemački narod ${ }^{34}$ ), ali ne bez rezerve prema jugoslovenskoj političkoj

30 „Što se tiče nemačkog pitanja, obe vlade smatraju da su u ovom trenutku, kada su na teritoriji posleratne Nemačke formirane dve suverene države, za njeno ujedinjenje neophodni pregovori između Savezne Republike Nemačke i Demokratske Republike Nemačke. One, takođe, smatraju da ostale države, pre svega super sile, moraju delovati u istom pravcu, kako u interesu nemačkog naroda, tako i u opštem interesu." Zajednička izjava Vlada Saveza Sovjetskih Socijalističkih Republika i Federativne Narodne Republike Jugoslavije, Moskva 20. jun 1956, u: „Jugoslovensko-sovjetski odnosi 1945-1956. Zbornik dokumenata,“ Beo$\operatorname{grad} 2010,914$.

${ }^{31}$ Prilikom susreta u Beogradu 1955. godine Hruščov i Tito su razgovarali i o nemačkom pitanju. Tito je smatrao da do ujedinjenja Nemačke treba doći uspostavljanjem kontakata između Istočne i Zapadne Nemačke. Treba priznati ravnopravnu koegzistenciju obe nemačke države, pustiti da nemački narod iskaže svoju volju, ne samo rukovodioci koji, po Titovom mišljenju, koče približavanje. Tu se već pokazalo da će se jugoslovenski stav uklopiti u tezu o dve nemačke države (AJ, CK SKJ, IX, 119/I-56; R. Luburić, Pomirenje Jugoslavije i SSSR-a 1953-1955, Podgorica 1999, 398-399). Naredne godine prilikom susreta u Moskvi Tito je izjavio da je ujedinjenje Nemačke stvar nemačkog naroda, kao i da je postojanje dve suverene nemačke države stvar političke realnosti, da jugoslovenska strana ima u vidu priznavanje NDR, ali da tom pitanju pristupa oportuno usled ekonomskih veza sa SRN. Hruščov se obavezao da će objasniti drugovima u NDR prirodu odnosa FNRJ-SRN. Zapisnik sa pregovora između sovjetske i jugoslovenske vladine delegacije od 5. juna 1956, u: „Jugoslovensko-sovjetski odnosi 1945-1956. Zbornik dokumenata“, prir. Lj. Dimić, M. Milošević, Đ. Borozan, I. V. Buharkin, L. V. Vnukova, J. A. Zelenko, M. K. Kravčenko, V. A. Soljanski, 873-874.

${ }^{32}$ Erlauschtes aus einem Gespräch Walter Ulbrichts mit dem jugoslawischen Botschafter, Neues Deutschland, 9. januar 1957, s. 3.

33 „Rüde' Prdvo" zu Jugoslawiens Deutschlandpolitik, Neues Deutschland, 14. April 1957, s. 7.

${ }^{34}$ Erlauschtes aus einem Gespräch Walter Ulbrichts mit dem jugoslawischen Botschafter, Neues Deutschland, 9. januar 1957, s. 3 Jugoslawische Regierung erklärt: Vereini- 
praksi, koja je kritikovana zbog održavanja diplomatskih odnosa sa Zapadnom Nemačkom u kojoj „vladaju militaristi,“ a ne sa Nemačkom u kojoj „moć poseduju oni koji se zalažu za mir." ${ }^{35}$ Ipak, gotovo su uvek kritike završavane optimističnom napomenom, izrazom vere u usmerenost jugoslovenske politike ka konstruktivnim, demokratskim odnosima koji neminovno vode i normalizaciji odnosa sa NDR, „kao što je J. B. Tito i naznačio u Moskvi.“" ${ }^{36}$ Takve nade izražavane kroz štampu verovatno je trebalo da deluju kao određeni javni pritisak na Jugoslaviju, podsetnik da je na njoj da preduzme korak ka zbližavanju, alarmiranje Bona da je postojanje NDR neminovnost.

Narednu prekretnicu u jugoslovenskom stavu prema nemačkom pitanju istočnonemačka štampa je videla u poseti poljske delegacije Beogradu septembra 1957. godine. U zajedničkoj poljsko-jugoslovenskoj izjavi uglavnom su ponovljeni odranije poznati jugoslovenski stavovi prema nemačkom pitanju, ali je praktičan korak predstavljalo priznanje poljskonemačke granice na Odri i Nisi. ${ }^{37}$ Štampa je i u Istočnoj i u Zapadnoj Nemačkoj izjavu tumačila kao korak ka uspostavljanju diplomatskih odnosa Jugoslavije sa NDR, zapravo kao „probni balon“ koji bi trebalo da odmeri reakcije Zapada. ${ }^{38}$

Diplomatsko priznanje Nemačke Demokratske Republike 15. oktobra 1957. predstavljalo je krunu evolucije jugoslovenskog stava prema nemačkom pitanju. Čitanjem istočnonemačke štampe može se sklopiti slika o zvaničnom jugoslovenskom stavu prema nemačkom pitanju tokom 1957. godine. Izostaju, međutim, dublja objašnjenja jugoslovenske spoljnopolitičke pozicije, motiva koji pokreću njenu spoljnu politiku. Čitalac stiče uvid u to da li je jugoslovenska politika „ispravna“ ili ne, ali ne i zbog čega se zauzima upravo takav stav. ${ }^{39}$

Istočnonemačka štampa prenosila je fragmente zvaničnih diplomatskih aktivnosti Jugoslavije tokom 1957. godine, dajući nešto potpuniju sli-

gung Sache der Deutschen. Bericht an das Parlament / Gute Beziehungen zu sozialistischen Staaten, Berliner Zeitung, 9. mart 1957, s. 1.

${ }^{35}$ Erlauschtes aus einem Gespräch Walter Ulbrichts mit dem jugoslawischen Botschafter, Neues Deutschland, 9. januar 1957, s. 3

${ }^{36}$ Realitäten in Deutschland, Neues Deutschland, 26. april 1957, s. 2.

${ }^{37}$ Oder-Neiße-Grenze endgültig. Gemeinsame polnisch-jugoslawische Erklärung unterzeichnet, Neues Deutschland, 19. septembar 1957, s. 1.

${ }^{38}$ AJ, 837, KPR, I-3-a/82-3, Pisanje zapadnonemačke štampe o Jugoslaviji, 14. oktobar 1957.

${ }^{39}$ Jugoslovenski stav prema nemačkom pitanju ogleda se u dokumentima o jugoslovensko-sovjetskim odnosima, videti zbirke dokumenata: Pomirenje Jugoslavije i SSSR-a 1953-1955, prir. R. Luburić, Podgorica 1999; Jugoslovensko-sovjetski odnosi 1945-1956, Zbornik dokumenata, prir. Lj. Dimić, M. Milošević, Đ. Borozan, I. V. Buharkin, L. V. Vnukova, J. A. Zelenko, M. K. Kravčenko, V. A. Soljanski, Beograd 2010. 
ku kada su u pitanju odnosi sa socijalističkim zemljama. To je verovatno proizilazilo koliko iz zainteresovanosti za političke aktivnosti unutar socijalističkog sveta, toliko i iz činjenice da je ADN uglavnom imala dopisnike u socijalističkim zemljama i saradnju sa tamošnjim novinskim agencijama, odakle je i preuzimala međunarodne vesti. Uglavnom su ti tekstovi bili kratki, informativni, mehanički preuzimani, bez ozbiljnijih analiza. Od tri korišćena dnevna lista, Nojes Dojčland je najažurnije prenosio vesti međunarodnog karaktera.

Odnosi Jugoslavije i narodnih demokratija bili su refleksija jugoslovensko-sovjetskih odnosa. Kakvi su bili jugoslovensko-sovjetski odnosi početkom 1957. godine? Određeni gubitkom poverenja nakon događaja $u$ Mađarskoj, sudarom različitih viđenja uzajamnih odnosa, ${ }^{40}$ ideološkim sukobom na liniji destaljinizacije/restaljinizacije, antijugoslovenskom kampanjom, koja je krajem 1956. godine otpočela u SSSR-u i u drugim istočnoevropskim zemljama, osudama jugoslovenskog držanja u mađarskoj krizi, ali i nacionalnog komunizma i sopstvenog puta u socijalizam, koje je jugoslovenska diplomatija prepoznavala kao implicitne napade na Jugoslaviju. ${ }^{41}$ Osnovni sukob se ipak odvijao izvan vidokruga javnosti, kroz tajnu prepisku J. B. Tita i N. S. Hruščova. ${ }^{42}$ Iako je jugoslovenskoj strani bilo u interesu da ne remeti međudržavne odnose i konflikt zadrži u ideološkoj ravni, sukob se odrazio i na ekonomskom planu, kao i na odnose Jugoslavije sa ostalim istočnoevropskim državama. ${ }^{43}$ Činilo se ipak da nijedna strana ne želi da zatvori sva vrata kao 1948. godine, stoga sukob nije prekinuo osnovnu tendenciju približavanja prisutnu od 1954, iako ju je vratio korak unazad.

$\mathrm{Na}$ početku 1957. godine ekonomska saradnja FNRJ sa socijalističkim zemljama bila je na silaznoj putanji, restaljinizovana rukovodstva napadala su nacionalni komunizam i samostalni put u socijalizam, antijugoslovenska kampanja $u$ javnosti uzimala je maha. Postojale su doduše razlike u oštrini antijugoslovenskih napada. Sa onim državama, uglavnom

${ }^{40}$ U februaru 1957, u trenucima zategnutih odnosa Beograda i Moskve, jugoslovenski ambasador V. Mićunović zapisao je svoje zapažanje suštine nesporazuma: „Ponovo se vidi da Rusi i mi ne prilazimo na isti način razvijanju saradnje među našim zemljama. Rekao sam već da su Rusi na to gledali kao na neku prethodnu etapu za naše približavanje, a zatim za naše uključivanje u lager. Mi smo pak na ove iste stvari gledali drukčije i nadali se da (...) radeći na ovaj način, najbolje pomažemo Rusima u ostvarivanju odluka 20. kongresa i politike destaljinizacije u SSSR-u i lageru." V. Mićunović, Moskovske godine 1956/1958, Beograd $1984,241$.

${ }^{41}$ V. Cvetković, Pogled iza gvozdene zavese. Jugoslovenska politika prema zemljama narodne demokratije u susedstvu 1953-1958, Beograd 2013; AJ, CK SKJ, (507), IX, 86/I-24, K-1, Antijugoslovenska propaganda u Istočnoj Nemačkoj.

${ }_{42}$ D. Bogetić, Nova strategija jugoslovenske spoljne politike 1956-1961, Beograd 2006, 72-73; V. Cvetković, n. d., 379.

${ }^{43}$ Isto, 377-380. 
susedima, sa kojima je Jugoslavija odranije imala sporove koji nisu bili vezani samo za ideološki sukob, odnosi su bili daleko više narušeni nego sa drugima. To su bile Bugarska, Mađarska, sa kojom je sukob oko podrške Imre Nađu i revoluciji bio svež i Albanija, čije je rukovodstvo bilo jedno od „najtvrđih“, staljinističkih, koje nije prihvatalo jugoslovensku partijsku liniju, ali sa kojom je Jugoslavija imala i druge konkretne ekonomske, pogranične, istorijske sporove.

Zategnutost $\mathrm{u}$ sovjetsko-jugoslovenskim odnosima imala je svoj izraz i u istočnonemačkoj štampi. Međutim, s obzirom na to da NDR nije imala neposrednih sukoba sa Jugoslavijom, u njoj nije objavljivan ni veliki broj samostalnih antijugoslovenski nastrojenih tekstova. Stoga se antijugoslovenska propaganda svodila uglavnom na prenošenje antijugoslovenski intoniranih izjava zvaničnika drugih socijalističkih zemalja. Iako je bilo osuda "nacionalnih elemenata" u Jugoslaviji i Poljskoj, kao i „samostalnog puta u socijalizam“, ${ }^{44}$ čini se da je to prvenstveno bilo u funkciji restaljinizacije same Jedinstvene socijalističke partije Nemačke. ${ }^{45}$

Interesovanje za Jugoslaviju je postojalo i u kontekstu njenog odnosa prema nemačkom pitanju, te je prvih meseci 1957. jugoslovenskoj diplomatiji prebacivano što održava odnose sa Zapadnom Nemačkom, a ne i sa Istočnom. ${ }^{46}$ Svakako je razlog izostanka intenzivnije antijugoslovenske kampanje bilo to što je Jugoslaviju ipak trebalo privoleti na diplomatsko priznanje, pa nije bilo uputno zatezati odnose. Možda je Jugoslavija za NDR, zaokupljenu sopstvenim problemima, bila previše "daleko“ da bi za nju bila zainteresovana izvan konteksta nemačkog pitanja i ideološke, partijske

${ }^{44}$ Unsere Verantwortung für ganz Deutschland erfordert Stärkung der DDR Aus der Rede des Genossen Heinrich Rau, Mitglied des Politbüros, auf einer Parteiversammlung am 18. Februar 1957 in der Warnowwerft, Rostock-Warnemünde, Neues Deutschland, 20. februar 1957, s. 3.

${ }^{45}$ SED je tokom 1956. prošla kroz različite faze. Nakon 20. kongresa KPSS na Trećem kongresu SED zapravo su ponovljeni ključni stavovi 20. kongresa o borbi protiv kulta ličnosti, demokratizaciji, decentralizaciji, jačanju zakonitosti. U drugoj etapi, podstaknutoj događajima u Mađarskoj, partijski vrh SED i dalje je podržavao demokratizaciju, ali je upozoravao na opasnost liberalizma, da bi u trećoj fazi stavovi izneseni na 29. i 30. plenumu SED faktički predstavljali negaciju Trećeg kongresa insistiranjem na borbi protiv revizionizma i negacijom nemačkog puta u socijalizam. AJ, CK SKJ (507), IX, 86/II-35-98, Jedinstvena socijalistička partija Nemačke (SED).

${ }^{46}$ Slična su zapažanja i u analizama CK SKJ iz 1958 - uočavalo se da rukovodstvo SED koristi antijugoslovensku kampanju za svoje „unutrašnje potrebe“ i za potvrdu politike 30. plenuma iz januara 1957. o „borbi protiv revizionizma.“ AJ, CK SKJ, (507), IX, 86/I-41, K-1, Angažovanje SED u antijugoslovenskoj propagandi u Istočnoj Nemačkoj 1958. - U analizi antijugoslovenske propagande u Istočnoj Nemačkoj još se zapaža da je kritika bila usmerena na dva pitanja: ekonomske teškoće, tumačene kao posledica uvođenja radničkih saveta i na nepostojanje diplomatskih odnosa sa NDR. AJ, CK SKJ, (507), IX, 86/I-24, K-1, Antijugoslovenska propaganda u Istočnoj Nemačkoj. 
linije. Kako je primećivano u Jugoslaviji, karakter antijugoslovenske propagande $u$ NDR ogledao se $u$ „prenošenju antijugoslovenskih izjava i članaka“ predstavnika drugih komunističkih partija, ${ }^{47}$ stoga ona kao izvor može i da naznači specifičnosti u odnosima Jugoslavije i pojedinih zemalja Istočne Evrope.

Promena u pisanju istočnonemačke štampe o Jugoslaviji uočljiva je od aprila 1957. kada je preneta vest o poseti albanske delegacije Moskvi i o Hruščovljevom govoru u kojem je isticao postojano poboljšanje sovjetskojugoslovenske saradnje (iako ta slika početkom aprila nije odgovarala realnosti) i želju za dobrosusedskim odnosima između Albanije i Jugoslavije. ${ }^{48}$ Čini se da je upravo taj govor bio signal iz SSSR-a da antijugoslovensku kampanju treba stišati. ${ }^{49}$ Istočnonemačka štampa posle toga nije prenosila izjave predstavnika istočnoevropskih država koje su sadržale kritički stav prema Jugoslaviji, kakav se nalazio u vestima iz prvih meseci 1957. godine.

Zastoj u jugoslovensko-sovjetskoj saradnji tokom prvih meseci 1957. godine odrazio se na pisanje istočnonemačke štampe o Jugoslaviji, ali vesti o zategnutim odnosima nisu prenošene. Stiče se opšti utisak da je, kada su u pitanju odnosi Jugoslavije sa SSSR-om i socijalističkim zemljama, istočnonemačka štampa uglavnom beležila i prenosila vesti o približavanju, bilo informativno, bilo u službi propagandnih tekstova o jačanju istočnog lagera. O pogoršanju u odnosima prenošena je samo ideološka, ne i državna dimenzija sukoba, čime se pružala simplifikovana slika međusobnih odnosa. Možda je u pitanju bio pokušaj da se ideološkim osudama kako narušava jedinstvo socijalističkog bloka, na Jugoslaviju prenese krivica za pogoršanje odnosa, time i odgovornost za izmirenje, koje bi bilo ostvareno promenom njenog stava prema lageru. Možda se strahovalo da bi iznošenje $u$ javnost zastoja u ekonomskim odnosima ${ }^{50}$ prenelo odgovornost za sukob na SSSR i

\footnotetext{
${ }^{47}$ AJ, CK SKJ, (507), IX, 86/I-24, K-1, Antijugoslovenska propaganda u Istočnoj Nemačkoj.

${ }^{48}$ Für gutnachbarliche Beziehungen. Chrustschow zum Verhältnis UdSSR - Albanien - Jugoslawien, Berliner Zeitung, 18. april 1957, s. 2; Brüderlich und geschlossen gegen die Reaktion. Abschluß der sowjetisch-albanischen Besprechungen / UdSSR verzichtet auf Rückzahlung von 348 Mill. Rubel, Berliner Zeitung, 19. april 1957, s. 2; Sowjetischalbanische Abschlußerklärung, Neues Deutschland, 19. april 1957, s. 5

${ }^{49}$ Vremenski se poklapa sa znacima zatezanja sovjetsko-kineskih odnosa.

${ }^{50}$ U decembru 1956. KPSS je donela odluku da otkaže dogovorene kreditne obaveze prema Jugoslaviji, što je objašnjavano „nedostatkom sredstava.“ Procena jugoslovenskog ambasadora u Moskvi Veljka Mićunovića bila je da su u pitanju „isključivo politički razlozi.“ Jugoslovenska delegacija je sa ciljem sklapanja trgovinskog ugovora i kreditnih aranžmana boravila u Moskvi od januara, a nakon skoro dva meseca sklopljen je samo trgovinski ugovor, koji je po rečima ambasadora V. M. bio „više nego skroman." Istočnonemačka štampa je o sklopljenom ugovoru pisala tek u aprilu, a o dvomesečnom boravku jugoslovenske delegacije u Moskvi, kao i odlaganju investicionih kredita, nije progovarala. O tome nije pisala ni
} 
otvorilo mogućnost da se odnosi poprave ekonomskom, ne nužno partijskom saradnjom. Možda se želela izbeći situacija iz 1948. kada se sukob vodio u javnosti. Sovjetski Savez verovatno nije želeo prekid, već samo pritisak. Sovjetski stav prema Jugoslaviji se u pisanju istočnonemačke štampe tokom prvih meseci 1957. mogao naslutiti samo kroz osude od strane drugih socijalističkih država, ali je o njemu direktno pisano uglavnom samo kroz konkretne poteze. Treba istaći i zapažanje CK SKJ da je antijugoslovenska propaganda u NDR zasnovana uglavnom na „prenošenju antijugoslovenskih izjava i članaka" predstavnika drugih komunističkih partija, pre svega KPSS, KP Francuske, KP Čehoslovačke, KP Kine. U štampi Istočne Nemačke, kao ni u drugim socijalističkim državama, uglavnom nisu objavljivani jugoslovenski odgovori na kritiku koja je stizala iz Sovjetskog Saveza i zemalja lagera. ${ }^{51}$ Brojne vesti informišu o saradnji ili spremnosti na saradnju, ali povremenim „spuštanjem“ do izvora dokumentarnog karaktera stiče se uvid u površnost, a neretko i netačnost štampe kao izvora za rekonstrukciju ekonomskih i političkih odnosa. Ona je češće bila sredstvo prenošenja određene poruke široj javnosti ili suprotnoj (u ovom slučaju jugoslovenskoj) strani, nego notar stvarnih događaja.

Jesen 1957. donela je „zahuhtavanje“ u jugoslovenskoistočnonemačkim odnosima $u$ vidu jugoslovenskog priznanja granice na Odri i Nisi prilikom posete poljske delegacije Beogradu u septembru, kao i diplomatskog priznanja i zaključivanja trgovinskog ugovora između FNRJ i NDR u oktobru te godine. Čin priznanja je istočnonemačka štampa predstavila kao „doprinos učvršćivanju mira u Evropi," odraz realnog postojanja NDR, međusobnih ekonomskih interesa, dobrih ekonomskih i kulturnih odnosa, političkog realizma jugoslovenskog rukovodstva, zajedničkih spoljnopolitičkih principa. ${ }^{52}$ Diplomatsko priznanje NDR od strane Jugoslavije kao vanblokovske zemlje, jedine osim SSSR-a koja je imala odnose i sa Saveznom Republikom Nemačkom, bilo je pitanje od primarnog unutrašnjeg i spoljnopolitičkog značaja za Istočnu Nemačku, što se odražavalo i u prostoru koji je tom pitanju posvećen u dnevnim listovima koje smo čitali. Ipak, većina vesti se ne bavi Jugoslavijom kao takvom, već navedeni događaj posmatra kroz prizmu nemačkog pitanja i odnosa sa Bonom. Jugoslavija, iako je subjekat u činu priznavanja NDR, u najvećem broju tekstova zapravo je objekat napada na Zapadnu Nemačku.

sovjetska štampa. V. Mićunović, Moskovske godine 1956/1958, Beograd 1984, 222, 226, 247; D. Bogetić, Jugoslavija u Hladnom ratu, 334-335.

Nemačkoj.

${ }^{51}$ AJ, CK SKJ, (507), IX, 86/I-24, K-1, Antijugoslovenska propaganda u Istočnoj

${ }^{52}$ Beitrag zur Festigung des Friedens in Europa, Neues Deutschland, 16. oktobar 1957, s. 1. 
Instrumentalizovanje Jugoslavije protiv Bona nije se prvi put dogodilo u oktobru 1957. u vezi sa diplomatskim priznanjem. Od početka 1957. u štampi su objavljivani tekstovi tematski posvećeni Jugoslaviji, ali čija je svrha bila napad na Zapadnu Nemačku.

Motivi napada su uglavnom bili osporavanje militarističkog i imperijalističkog karaktera zapadnonemačke spoljne politike koja predstavlja pretnju za mir, pokušava kroz zajedničko tržište da nametne svoju ekonomsku dominaciju Zapadnoj Evropi, a kroz NATO da se uključi u kolonijalnu politiku u Africi, od Bundesvera da napravi najjaču armiju u Evropi, a sigurno će posegnuti i za atomskim naoružanjem. Jugoslovenskoj diplomatiji je zamerano što ne osporava javno takvu politiku, koja direktno ugrožava Jugoslaviju - Bon je ekonomski već pokorio Austriju i nalazi se na granicama Jugoslavije, poput Hitlera. ${ }^{53}$ Prebacivano joj je što održava odnose samo sa SRN, ne i sa NDR, uz potenciranje miroljubivog i demokratskog karaktera istočnonemačke države. ${ }^{54}$

Često su napadi bili usmereni protiv civilnih i vojnih službenika Savezne Republike Nemačke koji su iza sebe imali nacističku prošlost. U takvim se tekstovima Jugoslavija pominjala ukoliko se biografija pojedinih ličnosti ukrštala sa jugoslovenskim prostorom. ${ }^{55}$

Događaj vezan za Jugoslaviju koji je izazvao koncentraciju tekstova usmerenih protiv Bona bila je poseta poljske delegacije Beogradu i priznanje granice na Odri i Nisi. Istočnonemačka štampa pratila je pregovore i njihov ishod, prenosila afirmativni odziv javnosti i zvaničnika NDR, ali je najveći prostor posvećen reakciji Bona. Objavljivani su naslovi poput „Bon se meša“, ${ }^{56}$ "Sramni napad Bona na Jugoslaviju“ ${ }^{57}$ „Bon peni“ ${ }^{58}$ „razljućeni

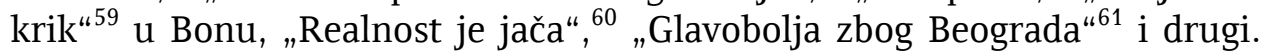
Najveći spoljnopolitički uspeh NDR u odnosu na SRN tokom 1957. godine bilo je diplomatsko priznanje od strane Jugoslavije. To je ujedno bila i prilika za propagandnu ofanzivu u štampi. Korišćena štampa pokazala se kao daleko opširniji, iako tendenciozni izvor za prilike u Zapadnoj Nemačkoj,

${ }^{53}$ Wo steht Jugoslawien in der Deutschlandfrage?, Neues Deutschland, 24. mart 1957, s. 5 .

${ }^{54}$ Erlauschtes aus einem Gespräch Walter Ulbrichts mit dem jugoslawischen Botschafter, Neues Deutschland, 9. januar 1957, s. 3.

${ }^{55}$ Verantwortlich für Ausplünderungen, Neue Zeit, 11. septembar 1957, s. 3.

${ }^{56}$ Bonn mischt sich ein, Neues Deutschland, 12. septembar 1957, s. 5.

${ }^{57}$ Ein unverschämter Angriff Bonns auf Jugoslawien, Neues Deutschland, 13. septembar 1957, s. 2.

${ }^{58}$ Bonn schäumt, Berliner Zeitung, 18. septembar 1957, s. 2.

${ }^{59}$ Ein unverschämter Angriff Bonns auf Jugoslawien, Neues Deutschland, 13. septembar 1957, s. 2.

${ }^{60}$ Die Realität ist stärker, Neues Deutschland, 18. septembar 1957, s. 2.

${ }^{61}$ Bauchschmerzen wegen Belgrad, Berliner Zeitung, 20. septembar 1957, s. 9. 
nego za Jugoslaviju. Pratila se i reakcija evropske štampe, kako komunističke, tako i „buržoaske.“62 Jugoslovensko priznanje NDR je uglavnom predstavljano kao najteži poraz Adenauera. ${ }^{63}$ Bon u ćorsokaku, ${ }^{64}$ Bon pred ruševinama svoje istočne politike $e^{65}$ - neki su od naslova koje je donosila istočnoevropska štampa prvih dana po priznanju.

Najžešći talas napada istočnonemačke štampe na SRN otpočeo je 19. oktobra, kada su prenete prve vesti da je zvanični stav Bona prekid diplomatskih odnosa sa Jugoslavijom, ukoliko ona ne povuče potez priznanja NDR, koji se tumači kao neprijateljski akt prema Saveznoj Republici Nemačkoj. ${ }^{66}$ Istočnonemačka štampa podvlačila je da je odluka Bona stav uskog kruga ličnosti, da nije čak postojala ni saglasnost vlade, a kamoli naroda, a da su opozicione partije istupile protiv prekidanja odnosa sa Jugoslavijom, kao i privredni krugovi zainteresovani za tržišta Istočne Evrope. ${ }^{67}$ Da su postojali partijski kontakti između NDR i zapadnonemačkih socijaldemokrata, istočnonemačka štampa ne govori. Objavljivanje takvih vesti značilo bi da se „miroljubiva“ Istočna Nemačka meša u unutrašnja pitanja drugih država. ${ }^{68}$

${ }^{62}$ Borba, Pravda Izvestia, Die Welt, Sueddeutschle Zeitung, Frankfurter Allgemeine Zeitung, Abendzeitung, Frankfurter-Rundschau, Der Spiegel, Manheimer Morgen, Neue RheinZeitung, Neue Oesterreich, Volksstimme, Reuter, Daily Ecpress, The Times, Le Figaro, Combat, Franc-Tireur, Stocholms Tiudingen, Morgon Tiudingen, Suenska Dagbladet, Ny Dag, Politiken, United, L'Humanite, New York Times, Trybuna Ludu, Rude Pravo ...

${ }^{63}$ „Schwerste Niederlage für Bonn seit Jahren“, Neues Deutschland, 17. oktobar 1957, s. 5.

${ }^{64}$ Bonn in der Sackgasse. Diplomatische Beziehungen DDR - Jugoslawien Thema Nr. 1, Neues Deutschland, 18. oktobar 1957, s. 5.

65 Bonn steht vor Trümmern seiner Ostpolitik. Geschäftiges Hin und Her in Westberlin und Bonn / Gerstenmaier und Ollenhauer „bedauern, Berliner Zeitung, 17. oktobar 1957, s. 1 .

${ }^{66}$ U pitanju je bio spoljnopolitički princip SRN uobličavan od 1949, a formulisan 1955. godine, poznat kao Halštajnova doktrina. Njom je podrazumevano da je diplomatsko priznanje NDR neprijateljski akt prema SRN i da će SRN prekinuti diplomatske odnose sa trećom državom ukoliko ona prizna NDR. Halštajnova doktrina je prvi put primenjena prema Jugoslaviji 1957. godine. Obrazloženje je bilo da priznanje dve nemačke države predstavlja prepreku ujedinjenju. Ona je imala funkciju prevencije lančanog priznanja NDR. Dušan Nećak, The Hallstein Doctrine and Yugoslavia, u: „Jugoslavija v Hladni vojni, Yugoslavia in the Cold War“, Ljubljana 2004, 215-221; M. Lemke, Alleinvertretungsanspruch, u: Deutsche Geschichte im 20. Jahrhundert. Ein Lexikon (ur. Axel Schildt), Muenchen 2005, 24-25.

${ }^{67}$ Bonn kündigt Abbruch der Beziehungen zu Belgrad an, Neues Deutschland, 19. oktobar 1957, s. 1-2.

${ }^{68}$ Analize SKJ donose podatke o politici SED. Kao prvi korak ka ujedinjenju Nemačke videli su zbacivanje Adenauera, te su stoga od proleća 1956. pokušavali da uspostave saradnju sa SPD, kako bi zajednički radili na rušenju Adenauera na izborima zakazanim za jesen 1957. godine. SPD je takvu saradnju odbijala. Uprkos odbijanju saradnje, istočnonemačka štampa je potencirala socijaldemokratsku opoziciju u SRN, možda ipak računajući na 
Prekid diplomatskih veza sa Jugoslavijom korišćen je za sveukupan napad na Adenauerovu politiku. Taj potez je predstavljan kao odraz političke tvrdoglavosti i gluposti, kao bezumni potez Adenauera, diplomatija kožnih jakni, mešanje u unutrašnje stvari suverene države koja podseća na spoljnu politiku Hitlera i carske Nemačke, izneveravanje principa za koje se Adenauer zalagao u predizbornoj kampanji, blokada ne samo odnosa sa Beogradom već celokupne istočne politike, izraz šovinističkih i revanšističkih tendencija, izraz ideje o svetskoj dominaciji, izraz nemačkog avanturizma koji je Evropu i svet već dva puta gurnuo u rat, znak slabosti, oživljavanje hladnoratovskih metoda, udarac normalizaciji političkih odnosa u Evropi. ${ }^{69}$ Slični motivi varirali su u različitim vestima koje su prenošene, a koje su imale istu funkciju - napad na Bon. Jugoslavija je u utakmici između Berlina i Bona imala sporednu ulogu.

Krajem oktobra tekstovi u istočnonemačkoj štampi posvećeni jugoslovensko-nemačkim odnosima, a usmereni protiv Bona, promenili su se i kvantitativno i kvalitativno. Njihova brojnost se smanjila, pošto se smanjio i broj konkretnih novosti, ali je akcenat sa kraćih vesti informativnog karaktera i pregleda svetske štampe stavljen na analize prethodnih događaja, ozbiljnije i promišljenije tekstove, koji imali i veću propagandnu težinu. Ipak, linije napada ostale su iste - osude za militarizam, imperijalizam, mešanje u unutrašnje stvari samostalnih država, oživljavanje Hladnog rata, oživljavanje tradicija Hitlera i Vilhelma II, personalizacija zapadnonemačke politike u liku Adenauera, fon Brentana i Halštajna i pozitivan odnos prema stavu socijaldemokratske opozicije. ${ }^{70}$

Iako je broj tekstova o Jugoslaviji bio veći, a tekstovi postajali duži, analitični, proširenog tematskog spektra, iako je o Jugoslaviji stvarana slika moderne industrijske socijalističke zemlje, u novembru i decembru su se

neki vid saradnje, ili na drugačiju istočnu politiku od Adenauerove. AJ, CK SKJ (507), IX, 86/II-35-98, Jedinstvena socijalistička partija Nemačke.

${ }^{69}$ In der Sackgasse der Irrealitäten. Eine Presseschau zur Haltung Bonns gegenüber Jugoslawien, Neues Deutschland, 20. oktobar 1957, s. 2; Bonn bricht diplomatische Beziehungen mit Jugoslawien ab. Herausfordernder Akt gegen Entspannung und friedliche Beziehungen, Neues Deutschland, 20. oktobar 1957, s. 1; Schritt gegen friedliche Koexistenz. Entschiedene Protesterklärung des jugoslawischen Botschafters, Neues Deutschland, 20. oktobar 1957, s. 1; Bonns „Selbstblockade“, Neues Deutschland, 20. oktobar 1957, s. 2 In der Sackgasse, Neues Deutschland, 22. oktobar 1957, s. 1; Bonn isoliert sich selbst. Beziehungen zu Jugoslawien abgebrochen, Berliner Zeitung, 19. oktobar 1957, s. 1; Kraftmeierei, Berliener Zeitung, 19. oktobar 1957, s. 2 Adenauer setzt Hitlers Politik fort, Berliner Zeitung, 20. oktobar 1957, s. 2.

${ }^{70}$ Wie sich die Bildergleichen. Das Wesen der Bonner Außenpolitik gezeigt am Schulfall Jugoslawien, Neues Deutschland, 28. oktobar 1957, s. 5; Gegen Abbruch der diplomatischen Beziehungen mit Jugoslawien, Neues Deutschland, 3. novembar 1957, s. 2; „Ostlandreiter" schließen sich zusammen, Neues Deutschland, 5. novembar 1957, s. 7. 
proredile vesti o političkom približavanju Jugoslavije i istočnoevropskih zemalja. Iz štampe se doduše nije mogla naslutiti razočaranost i revoltiranost sovjetske strane zbog izostanka J. B. Tita u Moskvi prilikom proslave 40 godina od Oktobarske revolucije „zbog išijasa, “" ${ }^{\text {M1 }}$ niti uverenje Sovjeta da je, kako je primećivao V. Mićunović, „Titova bolest političkog karaktera."72

Neposredna reakcija N. S. Hruščova na izostanak jugoslovenskog potpisa na Deklaraciji 12 komunističkih partija ogledala se u komentaru objavljenom u štampi krajem novembra 1957, da je potpisivanje dokumenta stvar dobrovoljne, slobodne odluke, da je jugoslovensko stanovište po pitanju prijateljskih odnosa sa Sovjetskim Savezom izraženo u Kardeljevom govoru u Moskvi, a da se pored toga na Manifestu mira nalazi potpis Saveza komunista Jugoslavije. ${ }^{73}$ Takva reakcija nije najavljivala buru koja je u jugoslovensko-sovjetskim odnosima nastupila na proleće naredne, 1958. godine. Međutim, retrospektivno gledano, verovatno su upravo događaji oko proslave jubileja Oktobarske revolucije bili prelomni za „drugi jugoslovensko-sovjetski sukob." Osnova sukoba bilo je različito viđenje odnosa unutar socijalističkog sveta. Moskva je težila konačnom uključivanju Jugoslavije u lager, a Jugoslavija očuvanju vanblokovske pozicije. Deklaracija je za jugoslovensku stranu imala karakter osnivačkog akta nove asocijacije komunističkih partija, što je ona želela da izbegne. Sovjetska strana je pak pokušavala da privuče Jugoslaviju perspektivom ekonomske i političke saradnje sa ideološki bliskim zemljama. Obe strane su istrošile argumente za odbranu svog viđenja međusobnih odnosa. ${ }^{74}$ Moskva ipak nije odmah pribegla pritisku na Jugoslaviju, do otvorenog sukoba i osuda došlo je tek posle usvajanja novog Programa SKJ na Sedmom kongresu SKJ aprila 1958. Razlozi zbog kojih reakcija Moskve nije usledila već u novembru 1957. bili su verovatno unutrašnje prirode, uzrokovani političkom krizom usled previranja u sovjetskom rukovodstvu, koja je prevaziđena početkom 1958. godine. ${ }^{75}$

Do kraja godine $\mathrm{u}$ istočnonemačkoj štampi nije bilo značajnih tekstova o političkom približavanju NDR i FNRJ, osim čestitki povodom Dana

71 Präsident Tito erkrankt, Neue Zeit, 31. oktobar 1957, s. 2; Präsidant Tito erkrankt, Neues Deutschland, 1. novembar 1957, s. 5

${ }^{72}$ V. Mićunović, $n$. d., 367.

${ }^{73}$ Wir kommunisten. Friedliche Koexistenz, Neues Deutschland, 29. novembar 1957, s. 5.

${ }^{74}$ A. S. Stukalin, Rukovodstvo KPSS v poiskah novbldž mehanizmov vlisniя na mirovoe kommunističeskoe dviženie. Ot Kominformbюro k pervomu bolbšomu moskovskomu sovemaniю kompartiǔ (vesna 1956- osenь 1957 g.), u: „Nasledniki Kominterna. Meždunarodnыe soveщаnія predstaviteleй kommunističeskih i rabočih partiй v Moskve (noяbr 1957 g.). Dokumentы“, prir. N. G. Tomlina, L. A. Veličanskaя, A. S. Stыkalin, Moskva 2013, 5-51.

${ }^{75}$ D. Bogetić, Drugi jugoslovensko-sovjetski sukob 1958. i koncept aktivne miroljubive koegzistencije, Istorija 20. veka, 2, 2004,123-128. 
Republike 29. novembra (treću godinu zaredom) ${ }^{76}$ i informacije o postavljanju Eleonore Štajmer za poslanika u Beogradu. To je, međutim, ostalo na nivou vesti, bez biografskih podataka koji bi skicirali profil prvog diplomatskog predstavnika NDR u Beogradu. ${ }^{77}$ Eleonora Štajmer, jedna od retkih žena u diplomatiji, bila je stručnjak za trgovinu i ekonomiju, što govori o važnom mestu privrednih odnosa u relaciji Beograd - Istočni Berlin. U prošlosti nije imala antijugoslovenskih istupa, bila je na čelu trgovinske delegacije u Jugoslaviji u oktobru, kada je ostavila pozitivan utisak. To ju je sve preporučivalo za poslanika u Beogradu, a činjenica da je bila ćerka predsednika NDR Vilhelma Pika svedoči o ukazanoj časti i nastojanju da se prida značaj odnosima sa Jugoslavijom, verovatno i pokušaj njihovog intenziviranja. ${ }^{78}$ Ipak, manji broj vesti i tekstova o Jugoslaviji u decembru 1957. možda je bio odraz "zatišja pred buru“ u jugoslovensko-sovjetskim, a time i jugoslovensko-istočnoevropskim odnosima.

Istočnonemačka javnost je godinama bila odsečena od jugoslovenske stvarnosti. Nije bilo diplomatskih predstavnika, trgovinskih predstavnika, turista, kulturne razmene, studentske razmene. Ne čudi stoga što ni u štampi Jugoslavija sve do jeseni 1957. godine gotovo da ne postoji kroz perspektivu bilateralnih istočnonemačko-jugoslovenskih odnosa, već iz vizure drugih socijalističkih zemalja. Slika Jugoslavije je u istočnonemačkoj štampi tokom 1957. godine kreirana ne samo ideološkim okvirima i političkim interesima vlasti NDR, već je bila ograničena onim korpusom vesti koje su nudile druge novinske agencije.

O Jugoslaviji je istočnonemačka štampa donosila fragmente realnosti i kao izvor može biti barometar spoljnopolitičkih kretanja Jugoslavije. Ti fragmenti pored toga što predstavljaju samo isečke jugoslovenske politike, a još manje donose o jugoslovenskom društvu, često su bili i obavijeni ideologijom, služeći određenom političkom ili propagandnom cilju, a ne izveštavanju o Jugoslaviji. Stoga su oni daleko bolji izvor za naslućivanje propagandnih ciljeva koje je nemačka strana želela da postigne, nego za rekonstruisanje jugoslovenske realnosti. Ove vesti mogu biti i izvor za mehanizme koji su korišćeni u propagandi. Štampa je trebalo da usadi određenu sliku Jugoslavije u svest čitalaca, da formira javno mnjenje, da pripremi čitaoce za određene političke događaje.

${ }^{76}$ DDR beglückwünscht Jugoslawien. Aus Anlaß des 12. Gründungstages der Föderativen Volksrepublik, Neue Zeit, 29. novembar 1957, s. 1.

${ }^{77}$ Zum Gesandten ernannt. Lore Staimer nach Belgrad / Urkunde aus der Hand des Präsidenten, Neues Deutschland, 21. decembar 1957, s. 5.

${ }^{78}$ M. C. Theurer, Bonn - Belgrad - Ost Berlin: Die Beziehungen der beiden deutschen Staaten zu Jugoslawien im Vergleich 1957-1968, Logos Verlag Berlin 2007, 41-42. 
Smatramo da analiza pisanja istočnonemačke štampe o Jugoslaviji tokom 1957. godine ima i poseban značaj u svetlu činjenice da je ona bila gotovo jedini izvor informacija o toj zemlji. U situaciji blokiranih političkih, privrednih, kulturnih odnosa do sredine 50-ih godina mediji, uključujući štampu, imali su monopol na informacije o Jugoslaviji u istočnonemačkom društvu. Stoga analiza pisanja o Jugoslaviji ukazuje i na znanja i predstave koje je stanovništvo, ali i Partija imala o Jugoslaviji uoči ponovnog uspostavljanja kontakata i diplomatskih odnosa 1957. godine.

\section{Natalija Dimić}

\section{THE IMAGE OF THE YUGOSLAVIA IN THE EASTGERMAN PRESS}

\section{IN 1957}

\section{Summary}

The newspapers of Eastern Germany (Neues Deutschland, Berliner Zeitung, Neue Zeit) printed articles regarding Yugoslavia that were directly influenced by political relations between Yugoslavia and the Soviet Union and by the need to secure a diplomatic recognition of Eastern Germany by a non-Allied country. As the motivating force for writing on Yugoslavia was of political origin, those articles mostly dealt with political issues. The articles mainly focused on Yugoslav-Soviet relations, the relations between Yugoslavia and other countries of Eastern Europe, Yugoslavia's stance regarding the German Question and relations between Yugoslavia and the GDR. The end result was that reporting on these topics was never complete and was far from accurate, the direct cause of which was the propagandist policies that were practiced by Eastern Germany at that time. Most of the articles on Yugoslavia during the first months of 1957 were chosen and reprinted from newspapers belonging to the communist countries (mainly from Moscow as well as from other Eastern European capital cities). In the second half of the year, in conjunction with diplomatic talks, there was the intent to print an increased number of articles concerning Yugoslavia. During that period, the articles became qualitatively different - more informative, longer, dealing with more diverse themes. This change was also rooted in an increased contribution from Eastern German reporters. However, as is typical with most reporting on Yugoslavia done at that time, the function of the articles was more important than the content. Politically influenced articles, especially those concerning diplomatic recognition, had above all the role of propagandist attacks at Bonn. Articles which painted Yugoslavia in a positive light and emphasized the success and advancements of Yugoslavia as a country were done with the intent to form a representative picture of Yugoslavia. The intent driving this type of reporting was two-fold: on one hand, the articles enhanced the meaning of Yugoslavian acknowledgement of Eastern Germany in the extra-political sphere, while on the other hand presenting a utopian vision of a socialist society. Reporting on Yugoslavia also played the role of self-denazification, with the desire to "cleanse" the country of any guilt related to WWII, and displace that guilt onto the "militaristic and imperialistic" elite of Western Germany. 